\title{
Development of a location-factor-matrix for sustainable business locations
}

\author{
M. Pajones ${ }^{1}$, T. Steiner ${ }^{1} \&$ N. Hackner-Jaklin ${ }^{2}$ \\ ${ }^{1}$ LOGISTIKUM Steyr, University of Applied Sciences Upper Austria, \\ Austria \\ ${ }^{2}$ WIGeoGIS, Austria
}

\begin{abstract}
Modern company strategies show that the issue of sustainability, for example in terms of corporate social responsibility (CSR) reports, became a significant aspect. However, related to the process of location planning, companies do not take sustainability into consideration. In consolidation of strategies in business economics, key objectives in spatial development and traffic planning, a sustainable business location should be generated. As no definition of the term "sustainable business area" exists so far, an inevitable step for further development is to create one, which is presented in this paper. Another aim is to identify essential location factors, which have an impact on the economic-, ecological- and social sustainability of business locations. A qualitative analysis of interdependencies demonstrates the substantial connections between these factors. In the course of an organized workshop, experts in freight logistics, spatial planning, traffic planning and sustainability discussed the essential location factors and their impact on sustainability. The output was a so called location-factormatrix for business locations. In a next step, the interdependencies among the defined location factors and their roles in the system have been indicated with the help of the impact matrix by Vester. Another substantial step further along the line will be the development of sustainability criteria or indices, which allow a classification of the business location. These findings will be an essential input for a location-factors-based evaluation and planning system.
\end{abstract}

Keywords: sustainability, location factors, sustainable business location, sustainable development, sustainability dimensions, impact matrix. 


\section{Sustainability: fundamentals}

At the beginning it is necessary to start with basic information in the field of sustainability, to precisely constitute our approach of this paper. The term sustainability is nowadays used in very different kinds of research and often referred to the definition by the United Nations, better known as the "BrundtlandReport" [1]:

"Sustainable development is development that meets the needs of the present without compromising the ability of future generations to meet their own needs".

Since the Brundtland Commission, many alternative definitions of sustainable development have been proposed, diverse interpretations of the concept have been made and it is not a simple concept to define [2]. As the "Brundtland definition" is very general, it is difficult to derive recommendations for action from it [3]. This allows a great deal of scope in terms of different sustainability concepts as well. To classify sustainable development into weak, strong and critical sustainability seemed most suitable for this approach. In this context the idea of weak sustainability means, that natural capital can be substituted by man-made capital. The concept of strong sustainability in contrast follows an approach, where natural capital cannot be substituted by man-made capital [4-7].

Zink et al. [4] states that, "Both concepts represent extreme positions and cannot be seen as directly applicable for our present way to sustainable development".

As enough space for further discussion and development between these two concepts was given, the idea of "critical sustainability" emerged. Within this approach, substitute of natural capital is possible in a partial way. It is necessary to define critical values of the availability of individual capital goods and to not cross these critical values $[4,6,7]$. Other concepts of sustainability are based upon the so called "three-pillar" or "triple bottom line" (Fig. 1) [2]. This approach allows separating sustainable development into an environmental-, social- and economical dimension.

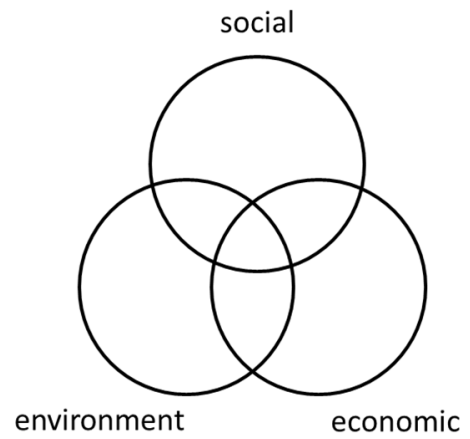

Figure 1: The "triple bottom line" or "three dimension" concept. 
The developments shown in this paper orientate themselves on the one hand to the concept of "critical sustainability" and on the other hand to the three dimension concept.

\section{Methodology}

\subsection{Literature review}

The roots of the location theory reach back to the beginning of the $20^{\text {th }}$ century. The book of Alfred Weber [8] deals with the question, what an ideal location of an industrial company needs. At this time, the inclusion of economic factors, e.g. transportation costs, was a novelty, which led to a trend-setting regard of the developed theories. Although present-day theories still tie in with Weber, noneconomic location factors, as the cultural activities, which are a part of the soft factors, became more important over time [9]. All these theories have in common that the location decision is always made from an entrepreneurial point of view with the aim of maximising the profit. Therefore, the proximity to the market and the transportation costs play a significant role. The idea of this paper however, analyses and evaluates the estate itself within the aspect of sustainability. Through the consolidation of long-term acknowledged location factors and new developed and soft factors, an evaluation with regard to economic, ecological and social sustainability is possible.

\subsection{Experts' workshop}

Experts of different research fields where invited to join a moderated workshop. Aims of the workshop were to define location factors, which have an input on sustainability, and to develop a definition for "sustainable business and industrial site". The joining persons were experts in the fields of sustainability, freight logistics, spatial planning, traffic planning, locations planning and geo information systems.

The first part of the workshop focused on defining business location factors, which have an economic, social or ecological (three dimensions) impact. As a result of the previous literature review, a list of important location factors, both hard and soft factors, was given to the experts for further discussions and working process. In this working process the experts sorted the factors in a systematic way and determined, if they have an economic, social or ecological impact. Factors which did not have any impact to the three dimensions were withdrawn from the list.

The second part of the workshop was dedicated on the question, "how to define a sustainable business and industrial site?" In this moderated session, the experts had group discussions and tried to find a suitable definition. First task was to define word phrases, which should be included in a final definition. In a final overall discussion, the phrases where brought together to develop a definition. 


\subsection{Interdependencies: impact matrix by Vester}

As part of the system dynamic topic, the impact matrix by Frederic Vester, which is part of the sensitivity model (SM) Vester and Hesler invented in 1975 [10], seemed suitable for the visualization of interdependencies among the different business location factors. The core ideas behind the SM, which distinguishes it from other planning methodologies, combine the issue of system thinking with a diffuse logic and a simulation using semi-quantitative data $[11,12]$. The system of the sensitivity model can be divided into nine steps (see Fig. 2).

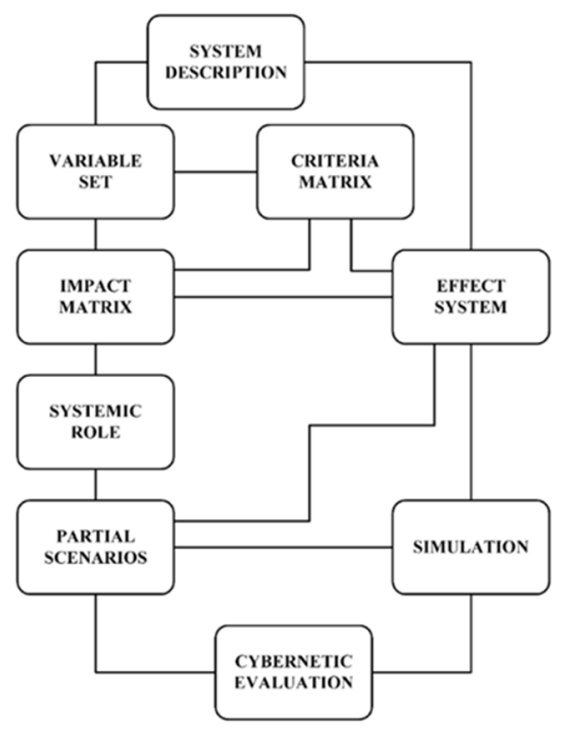

Figure 2: Sensitivity model.

For the development of this paper it was not necessary to go through the whole process up to the cybernetic evaluation. Therefore, only the first four steps till the impact matrix will be described explicitly. The first and most important step is to identify and describe the area of research in order to define a superior objective and consequently sub-goals. Afterwards, a set of influential variables, the location factors, have to be identified which, in this case, either show an ecological, an economical or a social influence on sustainability. As it is not possible to model all the different variables due to a lack of data availability, they have to be strained through an examination of the given information. Since the influence of the variables on sustainability have already been defined, it was not necessary to run the criteria matrix, which would have been the next step in the sensitivity model.

The most important questions were on the one hand how to show the influences between the selected location factors and on the other hand, how to demonstrate the interdependencies among them. Therefore, the cause-effect relations of the variables have been analysed with the help of the impact matrix, where a pair-wise comparison is made of each factor. Each cell in the impact matrix indicates the 
direct effect of the vertical on the horizontal variable. To show the influence of one factor on the other factors, the number 1 was set. If there was no effect between two variables a 0 was placed. The sum of each row (active sum - AS) and column (passive sum - PS) shows the value of the effect, which than indicates the role of every single factor. According to their value in the impact matrix, the roles of the variables can be active, passive, critical or buffering $[11,12]$. The findings out of this method will be used for the harmonization of a multivariate geo-data based location evaluation model.

\section{Findings}

\subsection{Definition of a sustainable business location}

Because no binding and comprehensive definition of a "sustainable business and industrial site" exists, it was necessary to develop one. The definition is needed to restrict the framework of the research in this work and for further development. It was developed within the expert workshop, which is described in chapter 2.1 of this paper. First task of the workshop was to define common word phrases, which should be included in a final definition. Therefore, the experts got into two groups to have a discussion. As output of this step the founded phrases were "[...] for future generations $[\ldots] "$, " $[\ldots]$ caring resources in developments $[\ldots]$ ", “[... access to resources $[\ldots]$ ", "[...] save the needs of $[\ldots]$ ", "[...] long-term competitiveness $[\ldots]$ ", “[...] long-term use of needed resources $[\ldots]$ ". After that step the experts had a final and moderated overall discussion to bring the phrases together into a single definition, which is as follows:

"A sustainable business- and industrial site supports a careful use of resources, specifically the natural capital stock. Long-term competitiveness, in meanings of economics and fulfilment of needs of the society are considered equally."

Ecology becomes a central part in this definition and references in this context to the resource land and its careful use. Beside land use also traffic becomes a necessary part in relation to ecology, because of the infrastructure (streets, motorways, railways, et.al.) where traffic takes place. To build up infrastructure, land is needed. The second pillar, economic sustainability, is expressed by "longterm competitiveness" and the social sustainability is expressed in the definition as "fulfilment of needs of the society". In summary, the definition above includes the three dimensions of sustainability, though highlighting the thoughts of ecology.

\subsection{Location-factor-matrix}

The theory on business locations was already discussed in Alfred Weber's “theory of the location of industries", at the beginning of the 20th century. In his work he investigated the ideal location for industrial companies. At this time, the 
implication of economic factors, such as costs of transport, was completely new and can be considered as a forward-looking approach. Modern theories tie to weber's work, but they have already expanded because of the technical progress. Today, so called "non-economic location factors", such as cultural offerings, get more and more important and assign to the so called "soft factors" [13]. What these theories all have in common is that location decisions for business and industrial sites are always taken by the companies themselves, which, of course, lay their focus on maximising the profit [14]. This is because issues such as closeness to sales market or costs on transportation have enormous influence on location decisions. The idea of this paper is to analyse and evaluate the location or real estate itself under aspects on sustainability. The approach in this paper is to combine long-term recognised location factors and new developed soft factors to analyse business and industrial sites on their economic, ecologic and social sustainability or their sustainability potential.

Based on literature review, with issue on location planning, and the findings of the experts' workshop, a matrix was developed which includes 33 location factors. All these factors have an influence on the sustainability of a business or industrial site. Table 1 shows some selected well-established location factors with their influence on the three dimensions of sustainability. The approach of classifying the location factors into the three dimensions is almost new. There are only few papers existing, which can be compared to this approach [15-17].

Table 1: Exemplary location-factor-matrix.

\begin{tabular}{|l|c|c|c|}
\hline Location factors & Economy & Ecology & Society \\
\hline Passenger traffic & - & $\checkmark$ & $\checkmark$ \\
\hline Freight transport & $\checkmark$ & $\checkmark$ & - \\
\hline Wage level* & $\checkmark$ & - & $\checkmark$ \\
\hline Demographic framework* & $\checkmark$ & - & $\checkmark$ \\
\hline Land price & $\checkmark$ & - & - \\
\hline Information technology & $\checkmark$ & $\checkmark$ & - \\
\hline Recreation and cultural offer* & - & - & $\checkmark$ \\
\hline Environmental quality* & $\checkmark$ & $\checkmark$ & $\checkmark$ \\
\hline *Of the scoping region. & & &
\end{tabular}

Although comparable literature concerning the classification exists, the proceeding of evaluating business sites by location factors which have an influence on sustainability can be seen as a new and innovative approach.

Passenger traffic, freight traffic and Information Technology are those factors which stand in direct connection to the location. The factor land price refers to the market price. The other factors refer to the region in which the business- and industrial site is located. Table 1 shows that the location factor "passenger traffic" has an influence on the ecological and social sustainability of the business- and industrial site. In contrast of that, the location factor "freight traffic" has an influence on the economic and ecological sustainability. These two factors assign 
to the so called "strong location factors". The factor "recreation- and cultural offer" is a typically example of the "soft location factors" and has an influence on the social sustainability of the business- and industrial site.

\subsection{Impact matrix}

The impact matrix indicates the different roles of the 33 business location factors of the developed location-factor-matrix. These roles can be active, passive, critical or buffering, resulting from the sums of the different rows and columns. In the matrix below (Fig. 3), the penultimate row shows the passive sum (PS) and the second to last column displays the active sum (AS) of the corresponding variables.

\begin{tabular}{|c|c|c|c|c|c|c|c|c|c|c|c|c|c|c|c|c|c|c|c|c|c|c|c|c|c|c|c|c|c|c|c|c|c|}
\hline Effect of $I$ on $\rightarrow$ & 1 & & 3 & & & 6 & & 8 & 91 & & & & & & $1617 \mathrm{rarab}$ & & 181 & & & & & & & & & & & & & & & & \\
\hline 1 Motorized individual traffic high-ranking & $x$ & 1 & 0 & 1 & 1 & 1 & 0 & $0 \times x$ & 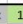 & 1 & 0 & 1 & 0 & 0 & 10 & 0 & 0 & 0 & 1 & 1 & 1 & 0 & 00 & & & 0 & 0 & 0 & 1 & 1 & 11 & 1 & 10 \\
\hline 2 Motorized individual trafficlow-ranking & 0 & $x$ & 1 & 1 & 1 & 1 & 0 & 0 & ? & 1 & 10 & 1 & 0 & 0 & 10 & 0 & 0 & 0 & 1 & 1 & 1 & 0 & 00 & 0 & & 0 & 0 & 1 & 1 & 1 & 11 & 1 & 133 \\
\hline 3 Not motorized individual traffic & 0 & 1 & $x$ & 1 & 1 & 0 & 0 & 0 & ) & 0 & 0 & 1 & 0 & 0 & 00 & 0 & 0 & 0 & 1 & 1 & & 0 & 00 & 0 & 1 & 0 & 0 & 1 & 1 & & & 1 & 163 \\
\hline 4 Public transporthigh-ranking & 1 & 1 & 0 & $x$ & 1 & 0 & 0 & 0 & 0 & 0 & 0 & 1 & 0 & 0 & 10 & 0 & O & 0 & 1 & 1 & 1 & 0 & 00 & 0 & 1 & 0 & 0 & 1 & 1 & 1 & & 4 & 127 \\
\hline 5 Public transport low-ranking & 1 & 1 & 0 & 0 & $\mathrm{x}$ & 0 & 0 & 0 & ) & 0 & 0 & 1 & 0 & 0 & 10 & 0 & 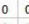 & 0 & 1 & 1 & & 0 & 00 & 0 & & 0 & 0 & 1 & 1 & 1 & & 1 & 108 \\
\hline 6 Parking area business location & 1 & 1 & 1 & 1 & 1 & $x$ & 0 & 0 & 0 & 0 & 0 & 0 & 0 & 0 & 00 & 0 & 0 & 0 & 0 & 0 & 1 & 0 & 00 & 0 & 0 & 1 & 0 & 0 & 0 & 1 & $\begin{array}{ll}0 & 0\end{array}$ & 0 & 267 \\
\hline 7 Freight traffic- Rail & 0 & 0 & 0 & 0 & 0 & 0 & $\mathrm{x}$ & 0 & 1 & 10 & 1 & 1 & 0 & 0 & 00 & 0 & 0 & 0 & 1 & 1 & & 0 & 00 & & 1 & 0 & 0 & 0 & & & & 11 & 157 \\
\hline 8 Freight traffic - Water & 0 & 0 & 0 & 0 & 0 & 0 & 1 & $\mathrm{x}$ & 1 & 0 & 1 & 1 & 0 & 0 & 00 & 0 & 0 & 0 & 1 & 1 & 1 & 0 & 00 & 0 & 1 & 0 & 0 & 0 & 0 & 1 & 10 & 0 & 1100 \\
\hline 9 Freight traffic-Road high-ranking & $x$ & 0 & 0 & 0 & 0 & 0 & 1 & 0 & 1 & 11 & 11 & 1 & 0 & 0 & 00 & 0 & 0 & 0 & 1 & 1 & & & 00 & & & 0 & 0 & 1 & & & & & 233 \\
\hline 10 Freight traffic - Road low-ranking & 0 & $\mathrm{x}$ & 0 & 0 & 0 & 0 & 1 & 0 & $x$ & 1 & 1 & 1 & 0 & 0 & 00 & 0 & 0 & 0 & 1 & 1 & 1 & 0 & 00 & 0 & 1 & 0 & 0 & 1 & 1 & 1 & & 1 & 163 \\
\hline 11 Freight traffic-Air & 1 & 1 & 0 & 1 & 1 & 0 & 0 & 0 & 1 & $1 \mathrm{x}$ & $<1$ & 0 & 0 & 0 & 0 & 0 & 0 & & 1 & 1 & & & 00 & 0 & & 0 & 0 & 1 & 0 & & & 1 & 300 \\
\hline 12 Transhipment terminal & 0 & 0 & 0 & 0 & 0 & 0 & 1 & 0 & 0 & 0 & $x$ & 1 & 0 & 0 & 00 & 0 & 0 & 0 & 1 & 1 & 1 & 0 & 00 & 0 & 1 & 0 & 0 & 0 & 0 & & & 1 & 113 \\
\hline 13 Transport safety & 0 & 0 & 0 & 0 & 0 & 0 & 0 & 0 & ) & 0 & 0 & $\mathrm{x}$ & 0 & 0 & 0 & 0 & 1 & 0 & 0 & 0 & 0 & 0 & 00 & 0 & 0 & 0 & 0 & 0 & 0 & & & & 6 \\
\hline 14 Wage level & 0 & 0 & 0 & 0 & 0 & 0 & 0 & 0 & 0 & 0 & 0 & 0 & $\mathrm{x}$ & 1 & 10 & 0 & 0 & 1 & 1 & 1 & 0 & 0 & 00 & 0 & 0 & 0 & 0 & 1 & & & & & 350 \\
\hline 15 Labor force potential & 0 & 0 & 0 & 0 & 0 & 0 & 0 & 0 & ) & 0 & 0 & 0 & 0 & $x$ & 0 & 0 & 0 & 0 & 1 & 1 & & 0 & 00 & 0 & & 0 & 0 & & & & & 14 & 133 \\
\hline 16 in- \& out-commuter ratio & 0 & 0 & 0 & 0 & 0 & 0 & 0 & 0 & 0 & 0 & 0 & 1 & 0 & 0 & $\times 0$ & 0 & 0 & 0 & 1 & 1 & & 0 & $\begin{array}{ll}0 & 0\end{array}$ & 0 & 0 & 0 & 0 & 0 & & & & 0 & 57 \\
\hline 17 unemplolyment rate & 0 & 0 & 0 & 0 & 0 & 0 & 0 & 0 & 0 & 0 & 0 & 1 & 0 & 0 & 0 & & 0 & 0 & & & & 0 & 0 & 0 & 0 & 0 & & & & & & $\begin{array}{lll}0 & 4 \\
\end{array}$ & 100 \\
\hline 18 Demography & 1 & 1 & 1 & 1 & 1 & 0 & 0 & 0 & ) & 0 & 0 & 1 & 0 & 1 & 0 & 1 & $\mathrm{x}$ & 0 & 1 & 1 & & & 00 & 0 & 0 & 0 & 1 & & & & & & 189 \\
\hline 19 Educational level & 0 & 0 & 0 & 0 & 0 & 0 & 0 & 0 & 0 & 0 & 0 & 0 & 1 & 0 & 0 & 1 & 1 & & 1 & 1 & & 0 & 00 & 0 & 0 & 0 & 0 & & & & & 06 & 150 \\
\hline 20 Enterprise density & 1 & 1 & 1 & 1 & 1 & 0 & 1 & 0 & 1 & 0 & 1 & 1 & 0 & 0 & 1 & 1 & 1 & 1 & $\mathrm{x}$ & 1 & 1 & 1 & 1 & 10 & & 1 & 0 & 1 & 1 & & & 1 & 90 \\
\hline 21 Spatiotemporal development of enterprise density & 1 & 1 & 1 & 1 & 1 & 0 & 1 & 0 & 1 & 0 & 1 & 1 & 0 & 0 & 1 & 1 & 1 & 1 & 1 & $x$ & & 1 & 1 & 10 & & 1 & 0 & 1 & 1 & & & 1 & 90 \\
\hline 22 Land price & 0 & 0 & 0 & 0 & 0 & 1 & 0 & 0 & 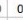 & 0 & 0 & 0 & 0 & 0 & 0 & 0 & & & 1 & 1 & & 0 & 0 & 00 & & 0 & 0 & 0 & & & & & 29 \\
\hline 23 IT & 0 & 0 & 0 & 0 & 0 & 0 & 0 & 0 & 0 & 0 & 0 & 0 & 0 & 0 & 0 & 0 & 0 & 0 & 1 & 1 & 1 & $x$ & 0 & 0 & 1 & 0 & 0 & 1 & 1 & & $\begin{array}{ll}0 & 1\end{array}$ & 1 & 175 \\
\hline 24 Energy & 0 & 0 & 0 & 0 & 0 & 0 & 0 & 0 & 0 & 0 & 0 & 0 & 0 & 0 & 0 & 0 & 0 & 0 & 1 & 1 & & 0 & & 0 & & 0 & 0 & 1 & & & & 18 & 400 \\
\hline 25 Supply unit \& disposal & 0 & 0 & 0 & 0 & 0 & 0 & 0 & 0 & 0 & 0 & 0 & 0 & 0 & 0 & 0 & 0 & 0 & 0 & 1 & 1 & & 0 & 0 & $x 0$ & 0 & 0 & 0 & 1 & 1 & 1 & $\begin{array}{ll}0 & 1\end{array}$ & 1 & 350 \\
\hline 26 Local taxes & 0 & 0 & 0 & 0 & 0 & 0 & 0 & 00 & 0 & 0 & 0 & 0 & 0 & 0 & 00 & 0 & 0 & 0 & 1 & 1 & & & 00 & b & 0 & 0 & 0 & 0 & 0 & 0 & & 0 & 300 \\
\hline 27 Existing vacancies & 0 & 0 & 0 & 0 & 0 & 0 & 0 & 00 & ) & 0 & 0 & 0 & 0 & 0 & 0 & 0 & 0 & 0 & 0 & 0 & 1 & 0 & 0 & 01 & & 0 & 0 & 0 & 0 & 1 & & \begin{tabular}{l|l|l}
1 & 4 &
\end{tabular} & 20 \\
\hline 28 Expandabilities & 0 & 0 & 0 & 0 & 0 & 0 & 0 & 00 & b & 0 & 0 & 0 & 0 & 0 & 0 & 0 & 0 & 0 & 0 & 0 & 0 & 0 & 00 & 00 & 1 & $x$ & 0 & 0 & 0 & 0 & 01 & 1 & 67 \\
\hline 295 chools 8 & 1 & 1 & 1 & 1 & 1 & 0 & 0 & 00 & ) & 0 & 0 & 1 & 1 & 1 & 0 & 0 & 1 & 1 & 1 & 1 & 0 & 1 & 0 & $\begin{array}{ll}0 & 0\end{array}$ & 0 & 0 & $x$ & 1 & 1 & 1 & $\begin{array}{ll}0 & 1\end{array}$ & & 1700 \\
\hline astrukture & 0 & 0 & 0 & 0 & 0 & 0 & 0 & 0 & ) & 0 & 0 & 0 & 0 & 0 & 0 & 0 & 1 & 0 & 1 & 1 & 1 & 0 & 0 & 00 & 1 & 0 & 0 & $x$ & 0 & 1 & \begin{tabular}{l|l}
0 & 0
\end{tabular} & 0 & 35 \\
\hline 31 Recreation \& & 1 & 1 & 1 & 1 & 1 & 0 & 0 & 00 & ) & 0 & 0 & 1 & 0 & 0 & 0 & 0 & 1 & 0 & 1 & 1 & & 0 & 0 & 00 & 1 & 0 & 0 & 1 & $x$ & & $\begin{array}{ll}0 & 0 \\
\end{array}$ & 013 & 50 \\
\hline 32 Environmen & 0 & 0 & 0 & 0 & 0 & 0 & 0 & 0 & ) & 0 & 0 & 0 & 0 & 0 & 0 & 0 & 1 & 0 & 1 & 1 & 1 & 0 & 0 & $\begin{array}{ll}0 & 0\end{array}$ & 0 & 0 & 0 & 0 & 1 & $x$ & $\begin{array}{ll}1 & 1\end{array}$ & 1 & 44 \\
\hline ature reserve & 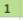 & 1 & 1 & 1 & 1 & 0 & 1 & 1 & 1 & 11 & 1 & 0 & 0 & 0 & 0 & 0 & 0 & 0 & 1 & 1 & 1 & 0 & 0 & 00 & 0 & 0 & 0 & 0 & 1 & 1 & & 1 & 121 \\
\hline 34 Economic promotions & 0 & 0 & 0 & 0 & 0 & 0 & 0 & 0 & 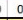 & 0 & 0 & 0 & 0 & 0 & 0 & 0 & 0 & 0 & 1 & 1 & 0 & 0 & 0 & $\begin{array}{ll}0 & 0 \\
\end{array}$ & 0 & 0 & 0 & 0 & 0 & 0 & $0 \quad x$ & & 9 \\
\hline & 10 & 12 & 8 & 11 & 12 & 3 - & 1 & 16 & 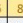 & 5 & 8 & 17 & 2 & 3 & 1 & 4 & 9 & 4 & 292 & 29 & 24 & 4 & 22 & \begin{tabular}{l|l}
2 & 1 \\
\end{tabular} & 20 & | & 1 & & & & & & \\
\hline & & & & & & & & & & & & & & & & & & & & 754 & & & & & & & & & 10233 & & & & \\
\hline
\end{tabular}

Figure 3: Impact matrix.

If, for example, a location factor has a comparatively high AS, such as "Enterprise density (20)" with 26, a change in this variable will have an extensive impact on the whole system and vice versa. The passive sum of a variable on the contrary shows if a strong influence from all the other factors is given (high sum) or not (low sum). For example, a small PS indicates that a lot can happen in the system until the variable changes, e.g. "Local taxes (26)".

The last row of the impact matrix shows the product (P) of AS and PS, whereas the last column indicates the quotient (Q) of AS over PS. The location factor with the highest product value (red cell - "Enterprise density (20)") can be stated as critical as it influences the others the most and in turn gets affected by the others the most as well. In contrast, the variable with the lowest product value (blue cell - "Local taxes (26)") has the role of the buffering factor, which means that it has a very low influence on all the other variables and at the same time gets influenced the least. The factor "Schools \& universities (29)" (purple cell), which has the 
highest quotient value, can be seen as an active element. This means that it has the greatest impact on all the other variables whereas at the same time gets influenced by the others the least. The passive factor (ochery cell - "Transport safety (13)") has a weak impact on the whole system while it is affected by the others the most. The roles of the different location factors help to understand the system as a whole and to identify the key leverages.

\section{Further need for research}

The results in this paper can be used as basic information for further research and development. The location-factor matrix lists location factors and shows their influence on the sustainability of the business- or industrial site. The impact matrix by Vester, which is based on the location-factor matrix, goes a step further. It shows the impact of the location factors among themselves. An advancement of Vester's impact matrix will show how strong the interdependencies among the different variables are. This will be a major input for the goal of the whole idea, which is the development of a geo-data based evaluation- and planning system, to analyse business- and industrial areas within the aspects of sustainability. A traffic optimized business- and industrial site should be the result of strategies in business economics, key objectives in spatial development and traffic planning, to ensure efficient and sustainable freight mobility. Therefore, further steps are needed. The first step is to develop and parameterize sustainability criteria, which can be applicable for business- and industrial locations. These criteria have to refer to the developed definition of a sustainable business and industrial site. In a second step, the criteria have to be quantified. To develop a geo data based evaluation- and planning system, data modelling, as third step, is needed. Involvement of future users of the evaluation- and planning system is necessary.

\section{References}

[1] WCED - World Commission on Environment and Development, Our Common Future, Oxford University Press: Oxford, New York, p. 41, 1987

[2] Pope, J., Annandale, D., Morrison-Saunders, A., Conceptualising sustainability assessment. Environmental Impact Assessment Review, 24, pp. 595-616, 2004

[3] Colsman, B., Nachhaltigkeitscontrolling - Strategien, Ziele, Umsetzung, Springer Fachmedien: Wiesbaden, p. 13, 2013

[4] Zink, K.J., Steinle U., Fischer, K., Human factors, Business Excellence and Corporate Sustainability: Differing Perspectives, Joint Objectives (Chapter 1). Corporate Sustainability as a Challenge for Comprehensive Management, ed. K.J. Zink, Physica-Verlag: Heidelberg, pp. 3-18, 2008

[5] Von Hauff, M., Nachhaltige Entwicklung - Grundlagen und Umsetzung, Oldenbourg Wissenschaftsverlag GmbH: München, pp. 58-60, 2014

[6] Hanley, N., Shogren, J.F., White, B., Introduction to Environmental Economics, Oxford University Press: New York, pp. 133-136, 2001 
[7] Busse, D., Nachhaltigkeitsaspekte in Theorie und Praxis der Entscheidungsfindung - Perspektiven institutioneller Steuerung in der Immobilienwirtschaft, Springer Fachmedien: Wiesbaden, p. 14, 2012

[8] Weber, A., Über den Standort der Industrie - Reine Theorie des Standortes, Verlag von J.C.B. Mohr: Tübingen, 1909

[9] Salmen, T., Standortwahl der Unternehmen. Tectum, 2001

[10] Vester, F., Die Kunst vernetzt zu denken - Ideen und Werkzeuge für einen neuen Umgang mit Komplexität, Deutscher Taschenbuch Verlag: München, pp. 185-229, 2002

[11] Chan, S.-L., Huang S.-L., A systems approach for the development of a sustainable community - the application of the sensitivity model (SM). Journal of Environmental Management, 72, pp. 133-147, 2004

[12] Huang, S.-L., Yeh, C.-T., Budd, W.W., Chen, L.-L, A Sensitivity Model (SM) approach to analyze urban development in Taiwan based on sustainability indicators. Environmental Impact Assessment Review, 29, pp. 116-125, 2007

[13] Salmen, T., Standortwahl der Unternehmen - Ein Überblick über empirische Gründe, Prozesse und Kriterien der unternehmerischen Entscheidungsfindung, Tectum Verlag: Marburg, p. 32, 2001

[14] Ishikawa, T., Dynamic Locational Phases of Economic Activity in the Globalized World, Springer Science+Business Media: Singapore, pp. 6998, 2016

[15] Kraus, S., Standortentwicklung unter nachhaltiger Perspektive - Ein ganzheitlicher Ansatz, Springer-Verlag, 2011

[16] Georges A. Tanguay, Measuring the sustainability of cities: An analysis of the use of local indicators, Elsevier, 2009

[17] Pajones M., Sustainability, geographical information system, site-related factors, 2016 